Brit. J. industr. Med., 1949, 1, 31.

\title{
HEALTH AND ENVIRONMENTAL CONDITIONS IN BRICKWORKS
}

\author{
BY \\ G. F. KEATINGE and N. M. POTTER* \\ From the Medical Department, The Butterley Co., Ltd., Derby \\ (RECEIVED FOR PUBLICATION, SEPTEMBER 2, 1948)
}

This survey is based on experience gained at three of the four brickworks of the Butterley Company Limited, in which altogether 144 persons are employed. At three of these works the "stiff plastic" process of manufacture is employed, but at the fourth the "wirecut" or "fully plastic" method is used. Since the workers employed are, at best, semi-skilled and tend frequently to change from one job to another, it is not possible to classify their occupations in an entirely satisfactory manner, but a rough list has been attempted as follows :

clay-getting
grinding and screening
brickmaking
tramming to kilns
setting
fitting and maintenance
burning
drawing
labouring (i.e., kiln cleaning and reloading
$\quad$ from stock)

The works owned by the Company are typical of a large number of brick-producing units which together yield a high proportion of the total bricks manufactured in England. The buildings and general environment are of a kind usually met with in the industry, and for this reason it is felt that conclusions based on the results of this survey can claim to give a fair picture of a considerable section of the brickmaking industry.

\section{The Clays and the Processes}

The so-called "clays" from which bricks are made in this country are mixtures of complex compounds of alumina and silica in widely varying proportions, together with impurities in the form of free silica, iron oxide, lime, magnesia, alkalis, and a certain amount of decomposed organic matter. Of these impurities, the most important

* Now Divisional Chief Scientist, National Coal Board, East Midlands Division. from the brickmaker's point of view is iron oxide. In the rare instances where little or none occurs the finished brick is a white or pale yellow colour. Three to 5 per cent. of iron causes a yellow to buff colour, and a higher proportion, up to 12 per cent., gives varying shades from salmon-pink to deep red. Even higher iron contents are occasionally met with, and such clays, if otherwise suitable, can be used for the manufacture of blue bricks. All the bricks produced at the works under review have an average iron content and burn to a red colour. The chemical constitution of the clay or shales from which such bricks are made is of the range given in Table 1.

TABLE 1

CHEMICAL CONSTITUTION OF CLAY OR SHALE USED FOR BRICKS AT BUTTERLEY COMPANY WORKS

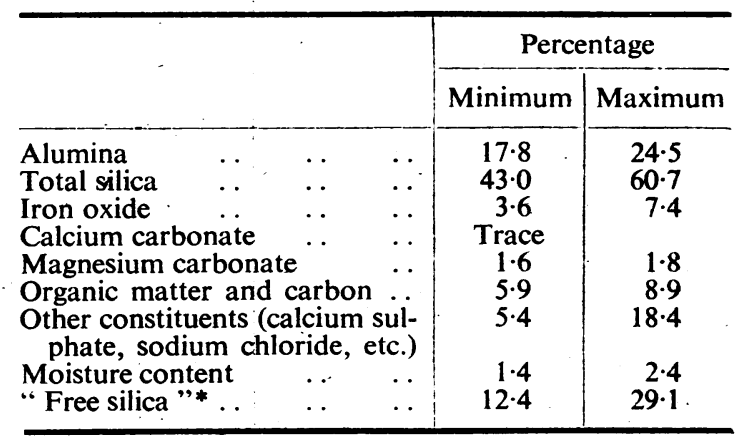

* By chemical analysis.

In three cases, the supply of material comes from a "clay hole" or quarry, adjoining the brickworks, but in the fourth it takes the form of shale from a nearby colliery.

Stiff Plastic Brickmaking.-In the case of bricks made by the stiff plastic process, the shale or clay is brought down from the quarry face by excavators and loaded directly into wagons which are trans. 
ported to the works by an endless chain or rope haulage system. It is then reduced to a fine powder in grinding pans. These pans have perforated bottoms, and as they revolve the material is crushed under heavy rollers; when fine enough it passes through the perforations into a pit, from which it is collected by a bucket elevator and delivered to the screening chamber. This is situated on the top floor of the building. In this chamber the ground material passes over sieves formed by a series of parallel wires, which take out the particles too coarse for brickmaking. Such particles gravitate back to the grinding pans. The material which passes through the sieves falls on to a stock-heap from which the brick machines are fed through holes in the floor. The brickmaking machine consists of a mixer, where sufficient water is added to form a stiff paste, and a pugmill or compression machine, which fills a series of moulds. The " clots" thus formed, are then automatically pressed into bricks. All machines of the stiff plastic type demand copious lubrication, both of the moulds and of the press dies, to prevent the adhesion of the clay paste to the metal. A continuous spray of oil is used for this purpose. The bricks are taken off the machine by hand and loaded on to trolleys. Having a moisture content of only about 18 per cent., they are stiff enough to be set directly into the kiln.

Wirecut or Plastic Brickmaking.-Here again the material is taken from the clay face by mechanical excavator and transported to the works by endlesschain haulage. The wagons are emptied into a feeder, from which the clay passes into a wet pan where water is added and the whole is milled into a plastic mass. The clay is squeezed through a series of slots in the bottom of the pan, after which it passes through several pairs of finely set crushing rollers and is delivered into a pugmill. From this machine it is extruded in a continuous column of very plastic clay, the cross-section of which is that of a green brick. This column is divided into three-foot lengths, which are then passed on to a removable pallet at right angles through a frame supporting parallel wires which cut the column into nine or ten bricks. The pallets are then loaded on to trolleys designed to carry about sixty bricks. Wirecut bricks at this stage of manufacture are too soft to permit being set directly into the kilns and they therefore spend a period of two or three days either on a heated drying floor or in some form of drying chamber, after which they are transported to the kiln.

TABLE 2

SHOWING THE COOLING POWER AS ASSESSED BY MEANS OF THE KATA THERMOMETER AND THE AIR TEMPERATURE IN DEGREES FAHRENHEIT FOR WET AND DRY BULBS (THE AIR VELOCITY IN FEET PER MINUTE IS ALSO OBTAINED FROM THESE READINGS)

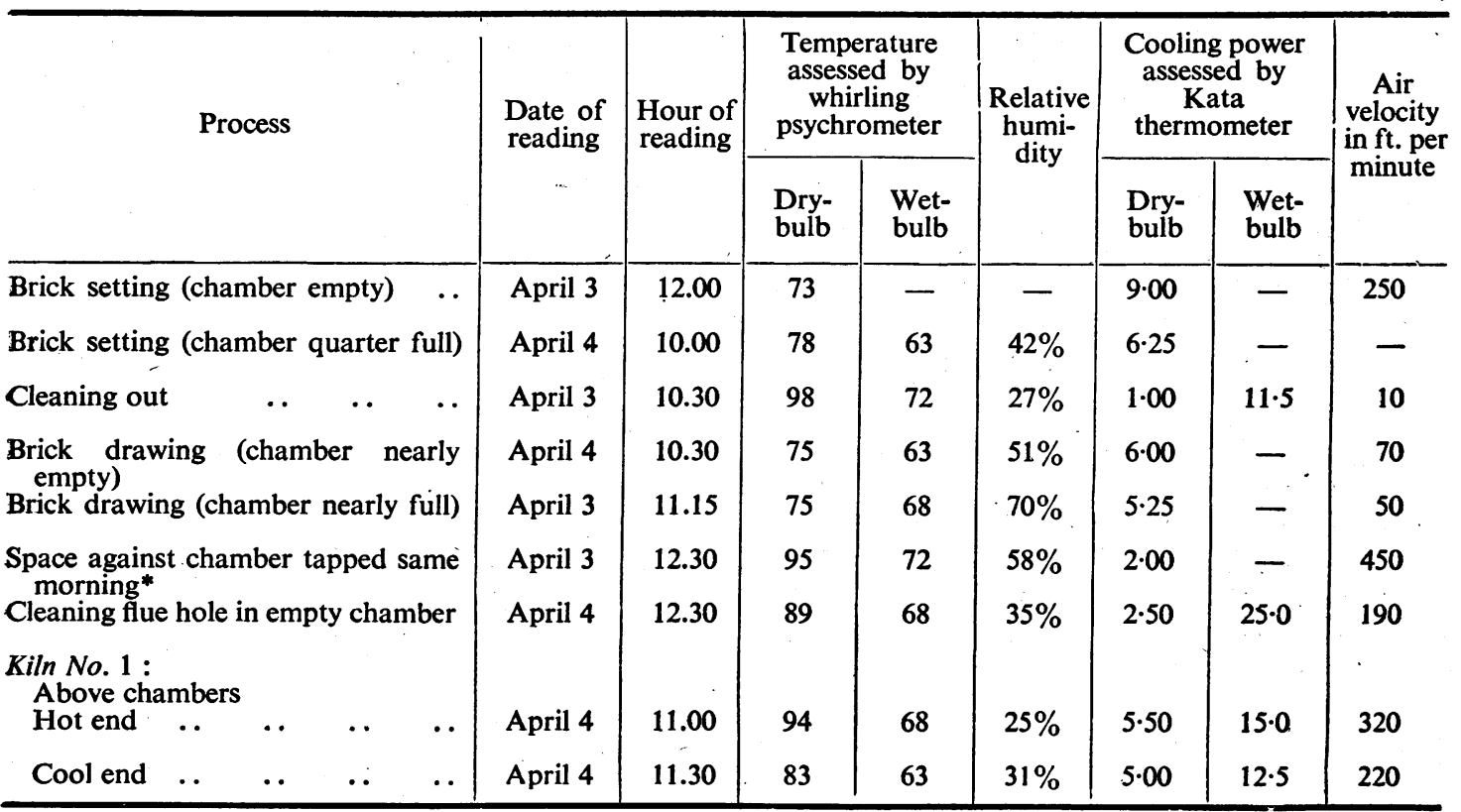

* This space was too hot to allow readings to be taken on arrival, but the figures given here were obtained some two hours later, that is, some five or six hours after tapping. 


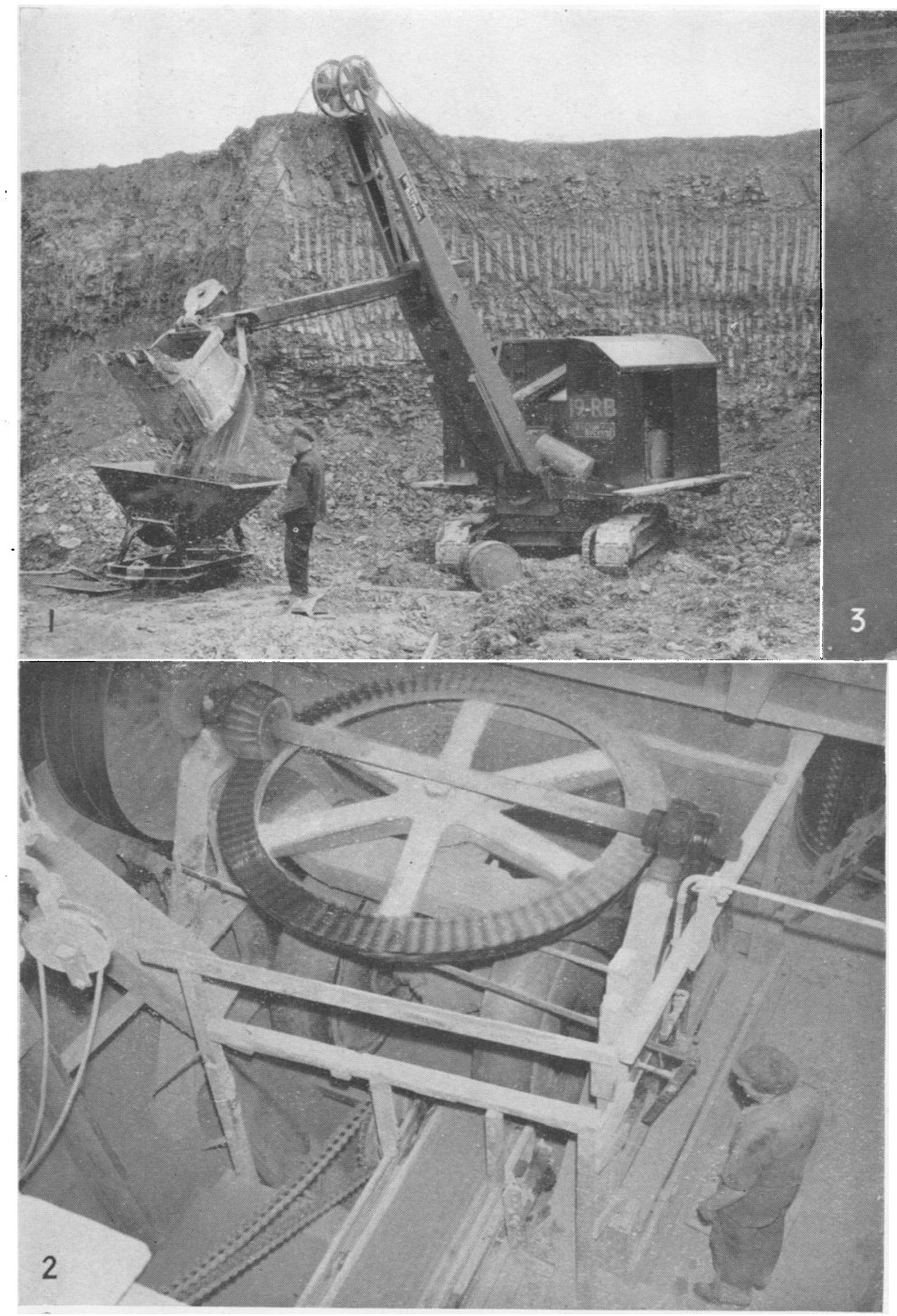

FIG. 1.-The excavator deposits clay into a wagon, which is moved by rope haulage up an inclined plane where the clay is transferred to a conveyor belt which carries it to the brickworks.

FIG. 2.-A view from above, showing the heavy rollers and grinding pans which reduce the clay to a fine powder.

FIG. 3.-The fine dust is raised by elevators from the grinding pans to the screens, one of which is seen in this picture. The workman is directing the flow of ground clay into the aperture through which it passes to the presses on the floor below.

Firing.-Brick kilns nowadays are generally of the continuous type which are constructed in a series of sixteen to twenty or more, so as to form a continuous tunnel. These kilns or chambers are set with bricks from floor to roof at the rate of about six to eight chambers per week. The bricks remain stationary in the kiln, but a body of fire circulates through the whole eighteen kilns in about three weeks.

During this time a chamber of bricks, after being set and the entrance to the kiln bricked up, undergoes a period of approximately three days' drying, six or seven days' pre-heating, three days during which actual firing takes place, followed by five to six days' cooling, after which the bricks are drawn and the chamber is cleaned out ready for refilling. The firing is done from the roof of the kilns, which are provided with small openings known as firing holes, to enable the coal to be introduced from above. Combustion takes place among the bricks.

\section{Environmental Studies}

Atmospheric Conditions. - The environmental studies were carried out at a stiff plastic brickworks. 


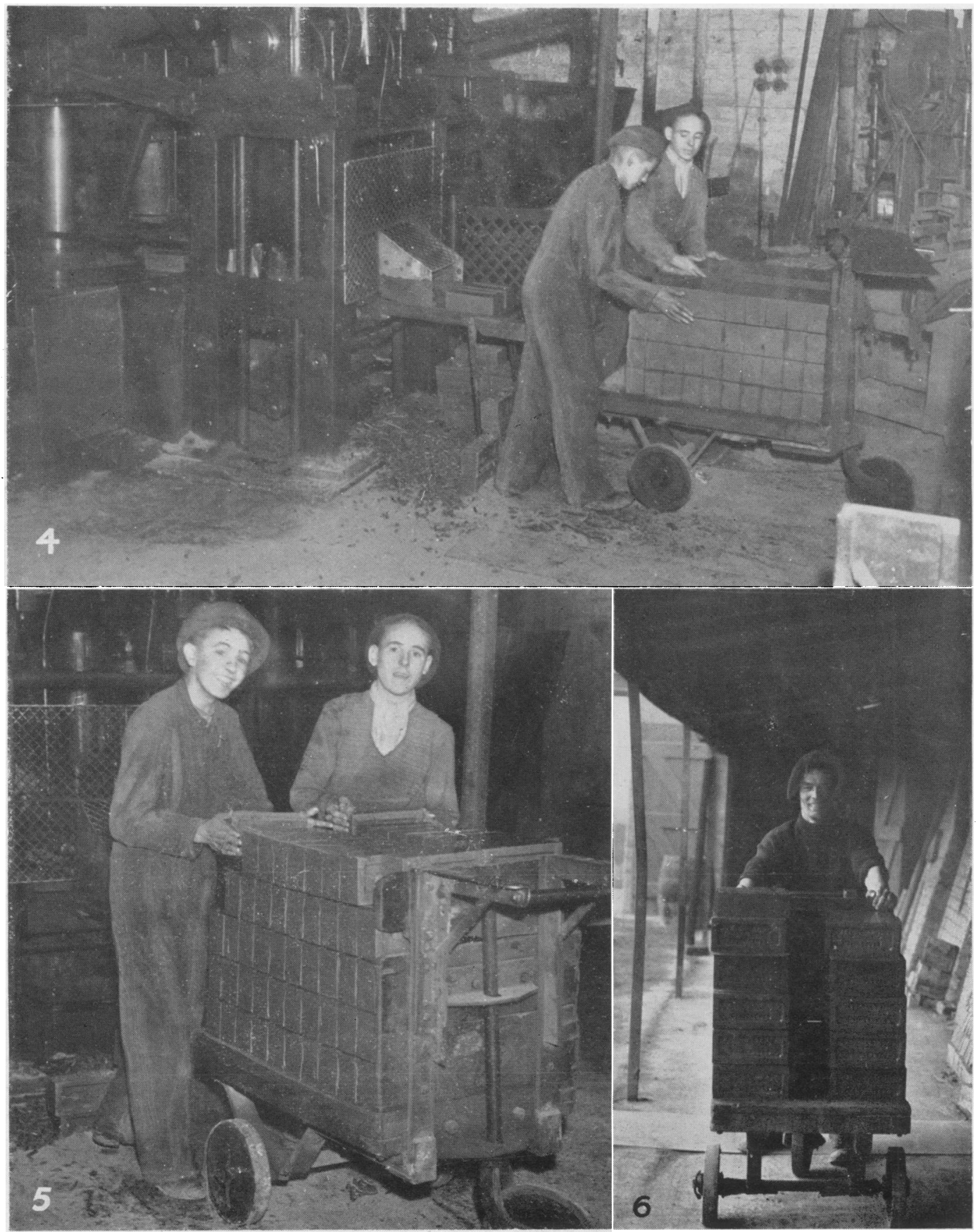

Fig. 4.-The process of taking the bricks off the press is done by hand. Note the careful guarding of a dangerous machine. Taking off the bricks brings the hands of those engaged on this work into contact with oil.

Fig. 5.-The bricks are stacked on a trolley and are then taken to the kiln.

FIG. 6.-The trolley is pushed by hand to the kiln along a covered way which, however, is open to the weatter on one side. 


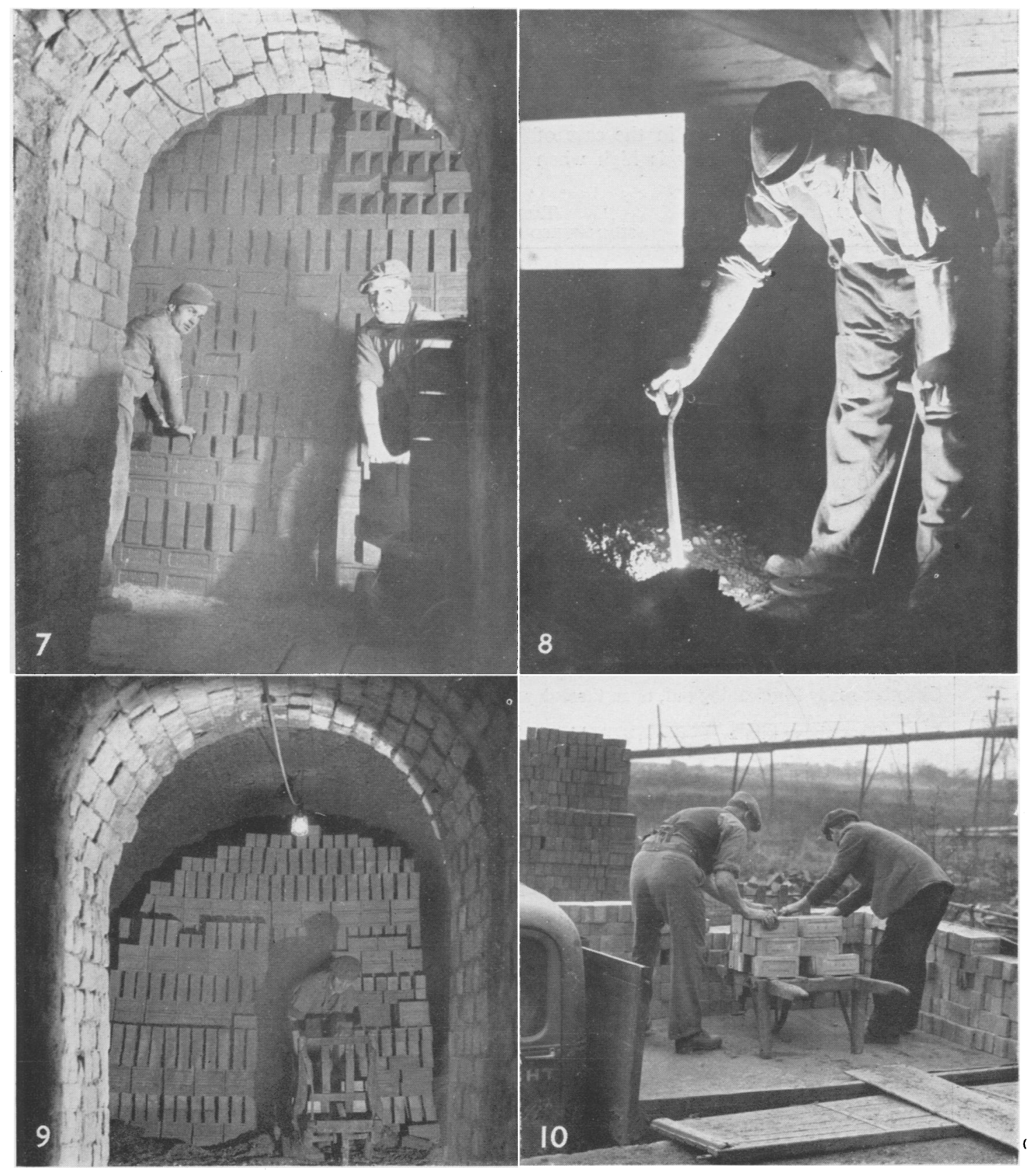

FIG. 7.-The green bricks are stacked by hand from floor to roof of the kiln.

Fig. 8.-Firing is done from above the kilns. The brick-burner is a highly-skilled person.

FiG. 9.-The bricks, having been fired and allowed to cool, are drawn off by hand.

Fig. 10. - The barrows are wheeled direct onto the waiting lorries, where the bricks are again stacked by hand. In the background can be seen the inclined plane by which the wagons reach the brickworks. 
Table 2, shows the results obtained with the Kata thermometer and the sling psychrometer. The temperature readings are high, ranging from $73^{\circ} \mathrm{F}$. to $78^{\circ} \mathrm{F}$., but such a state of affairs is inherent in the nature of the processes. As might be expected, the cooling power is rather low; in the case of brick-drawing the relative humidity is high when the chamber is full.
Dust Hazards. - The estimation of the dust risk was determined according to a technique similar to that previously described by us (Keatinge and Potter, 1945) and amplified subsequently in greater detail by one of us (Potter, 1946).

The Mass Concentration of Air-borne Dust.Twenty determinations of the dust hazard were under-

TABLE 3

SUMMARIZED OBSERVATIONS

\begin{tabular}{|c|c|c|c|c|c|c|c|c|c|c|}
\hline \multirow{3}{*}{$\begin{array}{l}\text { Sample } \\
\text { No. }\end{array}$} & \multirow{3}{*}{\multicolumn{6}{|c|}{ Operation and location }} & \multicolumn{2}{|c|}{$\begin{array}{l}\text { Mass concentration } \\
\text { (g. per } 1,000 \mathrm{cu} . \mathrm{ft} .)\end{array}$} & \multirow{3}{*}{$\begin{array}{c}\text { No. of } \\
\text { particles } \\
\text { per c.cm. } \\
5.5 \text { microns } \\
0.9 \text { microns } \\
\text { (3) }\end{array}$} & \multirow{3}{*}{$\begin{array}{l}\text { Sulphur- } \\
\text { dioxide, } \\
\text { parts per } \\
\text { hundred } \\
\text { million } \\
\text { of air } \\
\text { (4) }\end{array}$} \\
\hline & & & & & & & Below $5 \cdot 5$ & Whole & & \\
\hline & & & & & & & (1) & (2) & & \\
\hline 10 & Brick-drawing kiln 1 : & $\begin{array}{l}\text { Kilns } \\
\text { lamb }\end{array}$ & 8, & d 1 & & & 一 & $1 \cdot 2$ & 一 & - \\
\hline 2 & Brick-drawing kiln 2 : & namb & & . & $\ldots$ & . & - & $0 \cdot 5^{*}$ & - & 28 \\
\hline 13 & Brick-drawing kiln 1 : & namb & & dy) & $\cdots$ & . & - & $4 \cdot 6$ & - & 17 \\
\hline 18 & Brick-drawing kiln 1 : & lamb & & win & & . & $0 \cdot 12$ & $4 \cdot 9$ & 326 & 一 \\
\hline 1 & $\begin{array}{l}\text { Brick-drawing and cle } \\
\text { and } 10\end{array}$ & ng-o & kiln & $\mathrm{ch}$ & ber & 9 & - & $7 \cdot 2$ & - & - \\
\hline 19 & Cleaning-out kiln 1 : & Imbe & & . & . & . & $0 \cdot 12$ & $2 \cdot 7$ & 340 & - \\
\hline 24 & Chamber ready for cle & & op & & ays & .. & - & 一 & - & 76 \\
\hline 25 & Firing floor above kiln & & . & .. & . & . & - & 一 & - & 41 \\
\hline 8 & Stacking green bricks & & & & . & . & - & $0 \cdot 1$ & 一 & 40 \\
\hline 14 & Stacking green bricks & & & & . & .. & - & $0 \cdot 3$ & - & - \\
\hline 20 & Stacking green bricks & $2:$ & lam & & . & .. & 0.008 & 一 & 17 & - \\
\hline 6,17 & General body on grou & $\begin{array}{l}\text { st } M \\
\text { floo }\end{array}$ & ear & sses & . & $\cdots$ & 0.008 & $0 \cdot 2$ & 31 & - \\
\hline 7 & Top floor, outer room & scre & & $\cdots$ & . & $\cdots$ & 一 & 0.9 & 一 & $1:$ \\
\hline 15 & Top floor, outer room & scre & & . & . & . & 0.06 & $2 \cdot 0$ & 169 & - \\
\hline 3 & Top floor, screen B & $\cdots$ & & $\cdots$ & . & $\cdots$ & 一 & $4 \cdot 6$ & 一 & 一 \\
\hline 21 & Top floor, screen B & $\cdots$ & $\cdots$ & $\cdots$ & $\cdots$ & $\cdots$ & $0 \cdot 16$ & $3 \cdot 5$ & 601 & 一 \\
\hline 11 & Top floor, screen B & . & . & . & . & .. & - & $3 \cdot 7$ & - & 一 \\
\hline 4 & Top floor, screen A.. & $\cdots$ & $\cdots$ & $\cdots$ & . & $\cdots$ & 一 & $4 \cdot 6$ & 一 & 一 \\
\hline 16 & Top floor, screen A.. & $\cdots$ & . & $\cdots$ & . & $\cdots$ & $0 \cdot 15$ & $4 \cdot 8$ & 455 & 一 \\
\hline 22 & Top floor, screen A.. & $\cdots$ & . & $\cdots$ & . & $\cdots$ & 0.08 & $4 \cdot 2$ & 257 & - \\
\hline 5,12 & Top floor, screen A.. & $\cdots$ & . & $\cdots$ & . & . & 一 & $1 \cdot 2$ & 一 & 一 \\
\hline 23 & Top floor, screen A. . & . & . & . & . & .. & 0.02 & $1 \cdot 4 t$ & 105 & - \\
\hline
\end{tabular}

* This sample was a continuous one. Normally samples were discontinued when the kiln was not occupied. + This sample represented a place where the worker stood out of the dust when not needed at the screen. 
taken. These were carried out when workers were in the environment, each sample being taken by means of a hand pump attached to a filter. Eight of these were taken actually in the kilns, and the remaining twelve in the environment of the dust screen which feeds the crushed shale to the mixer. These were considered to be the dustiest occupations.

The cycle of operations in the kilns is (1) loading the green bricks ; (2) unloading the fired bricks out of the kiln; (3) cleaning out the coke and ashes from the kiln. Operations 2 and 3 may occur simultaneously.

At these times the highest mass concentration of dust was observed. The maximum concentration was $7 \cdot 2 \mathrm{~g}$. per $1,000 \mathrm{cu}$. ft.

The mass concentration of dust during emptying the kilns depends on outside conditions and whether the bricks are being removed from the mouth of the kiln or from the interior. The range was from $1 \cdot 2$ to $4.9 \mathrm{~g}$. per $1,000 \mathrm{cu}$. $\mathrm{ft}$. The dust is lodged on the tops of the bricks and is largely the ash from the coal which is fired from the top. When the brick is removed the ash is dislodged, and in windy weather the dust can cause physical discomfort.

There is very little dust associated with the stacking of the kilns with green bricks. An average concentration amounted to only $0 \cdot 2$ g. per 1,000 cu. ft.

To deal with the ground shale there are two screens in separate rooms each serving different moulding machines. In each room a worker is maintained to keep the feed constant. Here again, conditions are variable depending on the position of the operator, ventilation, and the dryness of the powder. Both rooms are very dusty. In one room a belt carries part of the dust to an outer room where it is delivered again to a hole in the floor. Owing to the open nature of this room and the small feed, the dust concentration affecting the operator is much lower than is the case for the other two workers.

The mass concentration near screen (A) varied from $1 \cdot 2$ to $4 \cdot 8 \mathrm{~g}$. per $1,000 \mathrm{cu}$. $\mathrm{ft}$., an average value being 3.2. The operator will tend to be in the lower concentration when he is standing away from the screen.

Near screen (B) the concentration varied from 3.5 to $4.6 \mathrm{~g}$. per $1,000 \mathrm{cu}$. $\mathrm{ft}$. and the average is 3.9 .

In the outer room adjoining screen (B) the concentration is not greater than $2 \mathrm{~g}$. per $1,000 \mathrm{cu}$. $\mathrm{ft}$. with a mean value of $1.4 \mathrm{~g}$.

Downstairs below the screens where the shale is being ground and the presses are working the average dust concentration is only $\mathbf{0 \cdot 2} \mathrm{g}$.

Numerical Concentration of Dust Particles.-Nine of the above samples were selected as generally representative, and the air borne dust was examined in order to assess the number of particles present in each cubic centimetre of air of a size which may be regarded as a potential hazard to health. Dust particles larger then 5.5 microns have been ignored

TABLE 4

PARTICLE FREQUENCY DISTRIBUTION OF AIR BORNE DUSTS*

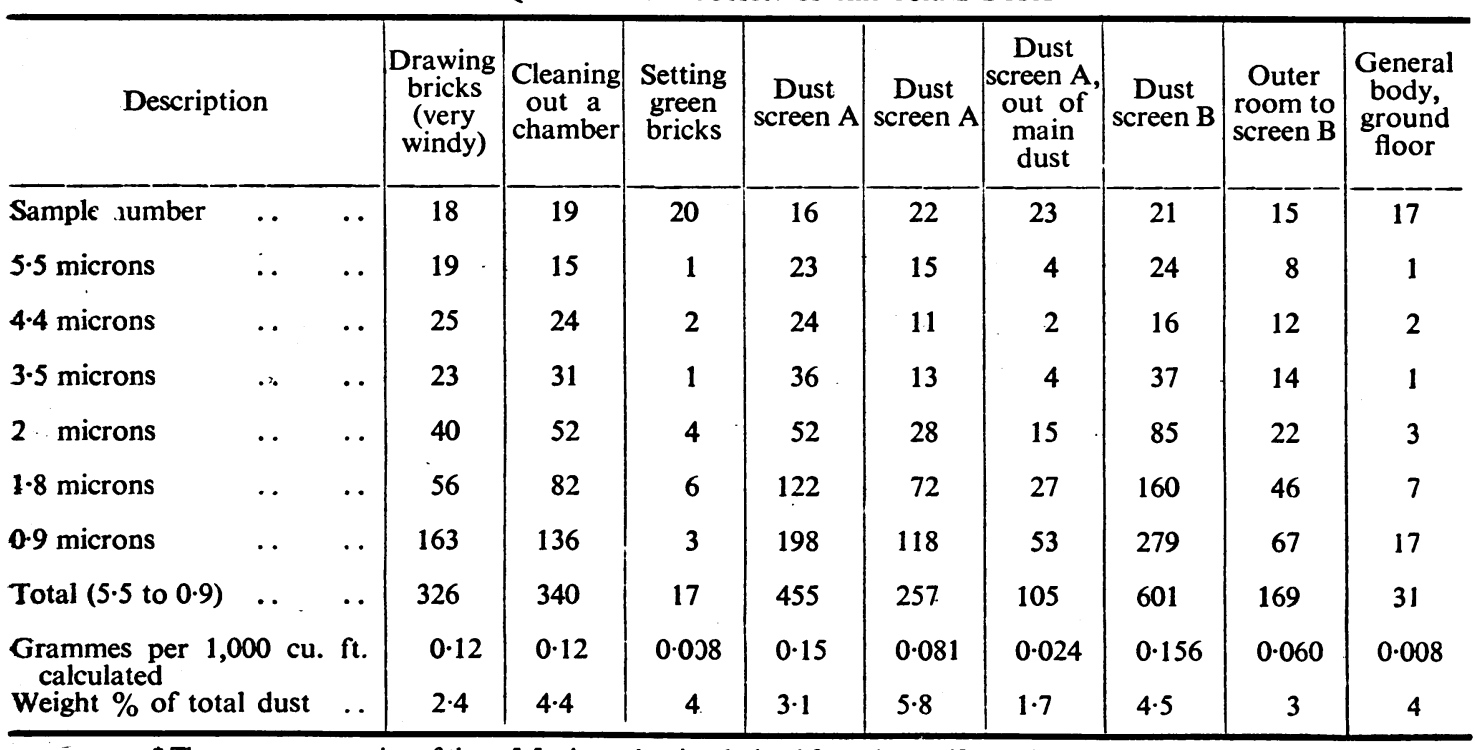


as have those smaller than $\mathbf{0 . 9}$ microns. (Normally the count would have been to include particles down to $\mathbf{0 . 5}$ microns, but the refractive index of the shale particles made examination in oil very unreliable.) A full count down to $\mathbf{0 . 5}$ microns would probably double the numbers given below, which are, of course, comparable with one another.

The highest number of particles was "near to screen (B) when 600 particles per c.cm. were recorded. In the room adjoining screen (B) the concentrations were much lower with 169 particles per c.cm. In the vicinity of screen (A) the lowest particle number recorded was 105 and the highest 455 , corresponding to the observed changes in mass concentration.

In the kilns the highest number was obtained during cleaning out, namely 340 particles per c.cm. Unloading kilns showed a high count, with 326 particles per c.cm., but the number was probably increased by windy conditions.

During the loading of a chamber with green bricks the number dropped to 17 particles per c.cm. This is comparable with conditions in the general body of the dust mill near the presses; where the number of particles per c.cm. was 31 .

Extent of Risk.-Although some of the dust concentrations are high, the chemical constitution of the dust is such that the danger from the inhalation of free silica in these brickworks cannot be great. Nevertheless the practice of water suppression as in use at one of the brickworks could well be extended, although it may be recalled that alumina has been shown to inhibit the fibrosisforming properties of free silica on the lung (Gardner and others, 1944). The process of manufacture of wire-cut bricks limits the risk of inhalation of dust to work in the kilns, where the hazard is comparable with that encountered in the firing of stiff plastic bricks.

Fumes.-During the cooling and cleaning of the chambers there appeared to be a considerable amount of fume present. This was tested for sulphur dioxide, hydrogen sulphide, and carbon monoxide, traces being found of the two first mentioned.

Sulphur Dioxide Concentrations.-Six measurements of the concentration of sulphur dioxide were made, five in the chambers and a sixth on top of the kilns: where the coal was being fired. A seventh test was carried out in the outside air. The measurements were all made after a week-end and in clear windy weather so that our recorded concentrations are probably somewhat lower than normal. Qualitative tests were made with the starch-iodate- iodine stain (Department of Scientific and Industrial Research, 1943) and quantitative measurement by means of the volumetric method, that is to say absorption of a known volume of air in dilute hydrogen peroxide solution, the sulphuric acid thus formed being titrated with $\frac{\mathrm{N}}{250}$ alkali. The concentrations are all expressed in parts per 100 million.

Above the kiln the concentration was 41. Coal is fed at intervals through the small opening by means of a hand shovel, the whole top floor is very open and only one man is employed at each shift. It was noticed that fumes were emitted from the top of the lids after firing.

A chamber which was ready for cleaning out, having been open for three days, gave the highest concentration - of 76. This was on the windward side. Two chambers being unloaded, one on either side of the kiln, gave concentrations of 28 and 17 respectively. In a chamber that was being loaded with green bricks the concentration was rather high at 40 .

The normal air external to the brickworks was exceptionally free from sulphur dioxide, and certainly did not exceed 5 . This is very low indeed, and indicates that mixing conditions in the atmosphere were very good.

Carbon Monoxide Concentration:-The palladium chloride reaction was the method used for the estimation of carbon monoxide. (Department of Scientific and Industrial Research, 1943.)

Tests were carried out above the kilns (from where the stoking is done) and in the chambers during cleaning out. No reactions whatever were noted for concentrations of 1 in 12,000 or less. Concentrations of 1 in 10,000 or less are regarded as harmless for practical purposes.

Hydrogen Sulphide Concentrations.-The Leadacetate test was used for the estimation of this gas (Department of Scientific and Industrial Research, 1943).

Tests were carried out above the kilns, at the entrance to a chamber just tapped, and in a chamber during cleaning out. All three positions gave positive results, but the concentrations were yery low, namely considerably less than one part per $1,000,000$ in the first two positions and less than one part per 500,000 in the chamber during cleaning out.

Mineral Oil.-Although it has not been possible to find out the country of origin of the oil, it has a specific gravity of 849 and its refractivity is within the range of 5,540 to 5,500 , so that on the basis of these findings its carcinogenic properties should not be high (Twort and Lyth, 1933). 


\section{Health Studies}

A study of the occupational mortality figures in the Registrar General's Decennial Supplement (1931) relating to " makers of bricks, unglazed tiles, kiln and oven men not making earthenware, china or terra cotta," although apt to be misleading in some respects, nevertheless shows the low ratio of eightyseven in each of the above groups expressed as a standardized mortality rate.

One hundred and forty-four men are employed, and of these one hundred have been submitted to medical examination, while radiography of the chest was carried out in seventy-three cases. Two of the brickworks have recently been re-opened and all those starting work in them-thirty-seven persons-have been examined. The remaining sixty-three have all been employed at a larger brickworks and were examined on a routine survey, which included all save three of the workers.

The average length of employment in the brickworks industry was 7.88 years per worker. The results of the investigation are given in Tables 5 , 6 , and 7 , and it will be noted that the physical condition of those examined was on the whole satisfactory. These findings therefore afford confirmatory evidence of the good standard of health of the brickworkers; nevertheless it must be borne

TABLE 5

SHOWING PHYSICAL DEFECTS FOUND IN ONE HUNDRED PERSONS EXAMINED AT FOUR BRICKWORKS OF THE BUTTERLEY COMPANY LIMITED

\begin{tabular}{|c|c|c|c|c|}
\hline \multirow{2}{*}{$\begin{array}{l}\text { Physical defects } \\
\text { found } \\
\vdots\end{array}$} & \multicolumn{4}{|c|}{$\begin{array}{l}\text { Number of persons in } \\
\text { each age group (years) } \\
\text { showing such defects }\end{array}$} \\
\hline & $\mid 14-25$ & $26-35$ & $|36-45|$ & Over 46 \\
\hline No physical defect noted & 10 & 11 & 3 & 1 \\
\hline Respiratory conditions & 1 & 3 & 1 & 2 \\
\hline Enlarged tonsils & 9 & - & - & - \\
\hline Dental conditions & 6 & 4 & 4 & 2 \\
\hline Reduced vision & 2 & 4 & 2 & 7 \\
\hline Low mental grade & 1 & 1 & - & 1 \\
\hline $\begin{array}{l}\text { Defects of cardio- } \\
\text { vascular system }\end{array}$ & - & 1 & 5 & - \\
\hline $\begin{array}{l}\text { Defects of central } \\
\text { nervous system }\end{array}$ & 3 & 1 & 1 & 1 \\
\hline $\begin{array}{l}\text { Hernia and weakness in } \\
\text { inguinal rings }\end{array}$ & 2 & 2 & 1 & 2 \\
\hline Skin $\quad \cdots, \quad \cdots$ & 7 & 4 & 1 & 1 \\
\hline Miscellaneous & 7 & 6 & 12 & 1 \\
\hline Total & 48 & 37 & 30 & 18 \\
\hline
\end{tabular}

TABLE 6

SHOWING LUNG CHANGES IN SEVENTY-THREE MEN $\boldsymbol{x}$-RAYED AT FOUR BRICKWORKS OF THE BUTTERLEY COMPANY LIMITED

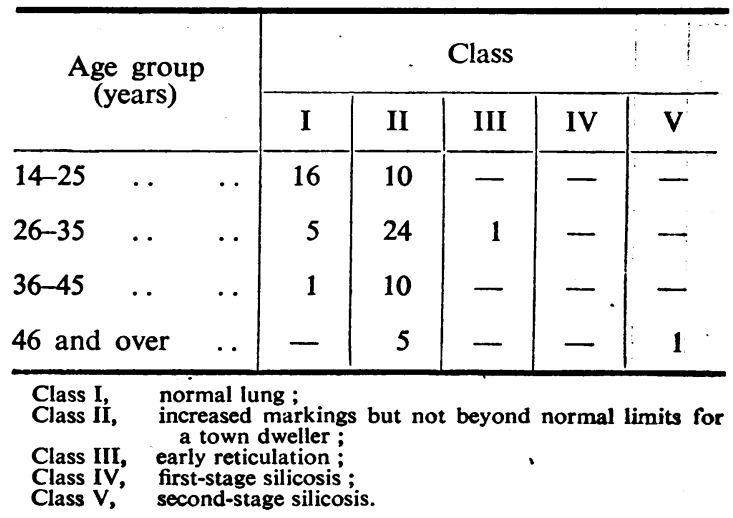

in mind that the vast majority examined were young men whose physical condition might be expected to be good. The radiographic appearances of the lungs were singularly free from changes due to dust, although in only two cases had there been a dust hazard of any magnitude. These were both young men, aged 25 and 22 , who had been working in the dust mill for a considerable time; but even in them the changes due to dust were minimal.

One new entrant to the brick-making industry, a man aged 49, showed radiographic appearances indistinguishable from classical silicosis. He had previously been a bricklayer's labourer, and the changes seen in the lung therefore remain unexplained, although we have from time to time observed early dust changes in the lungs of bricklayers and their labourers.

Two cases showing keratotic changes in the skin were seen in men aged 46 and 36, who had been exposed to mineral oil for a long time; biopsy, however, showed no evidence of malignant changes. The occurrence of skin effects following the use of mineral oil in brickworkers has been noted previously (Henry, 1946) but needs to be stressed.

Only one compensatable accident took place during the twelve months in which this survey was being conducted. . This was a case of amputation of the terminal portions of the distal phalanges of the third and fourth fingers of the right hand in a boy aged fifteen years who was operating a brick press.

\section{Discussion}

The possible hazards of brickworkers are : (1) dermatitis and keratotic changes in the skin associated with the use of mineral oil ; (2) the inhalation of dust in those working in the mills; 
TABle 7

OCCUPATIONAL HISTORY AND PHYSICAL DEFECTS FOUND ON EXAMINATION OF WORKERS EMPLOYED AT FOUR BRICKWORKS OF THE BUTTERLEY COMPANY LIMITED

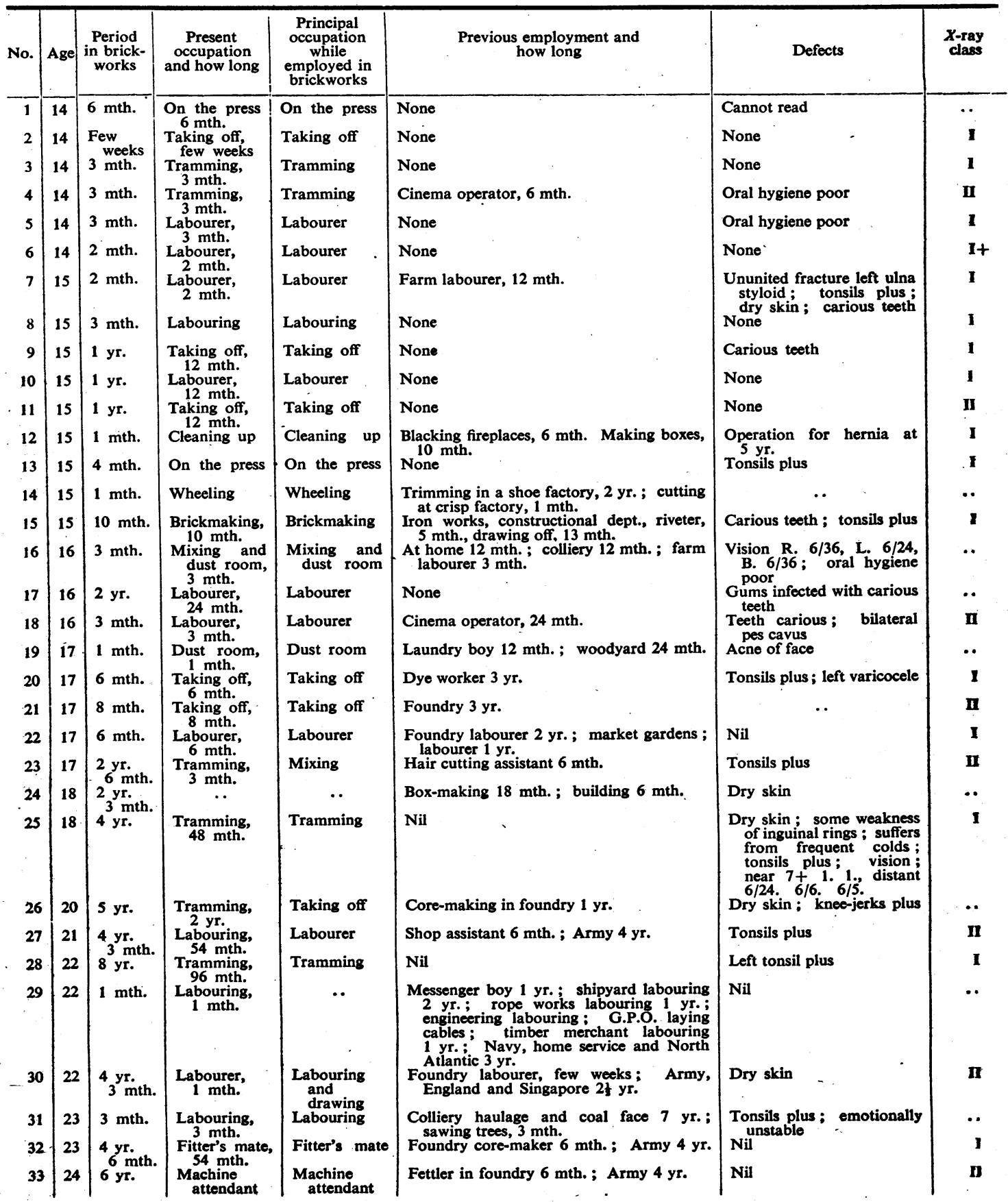

(Continued on next page) 
TABLE 7-(continued)

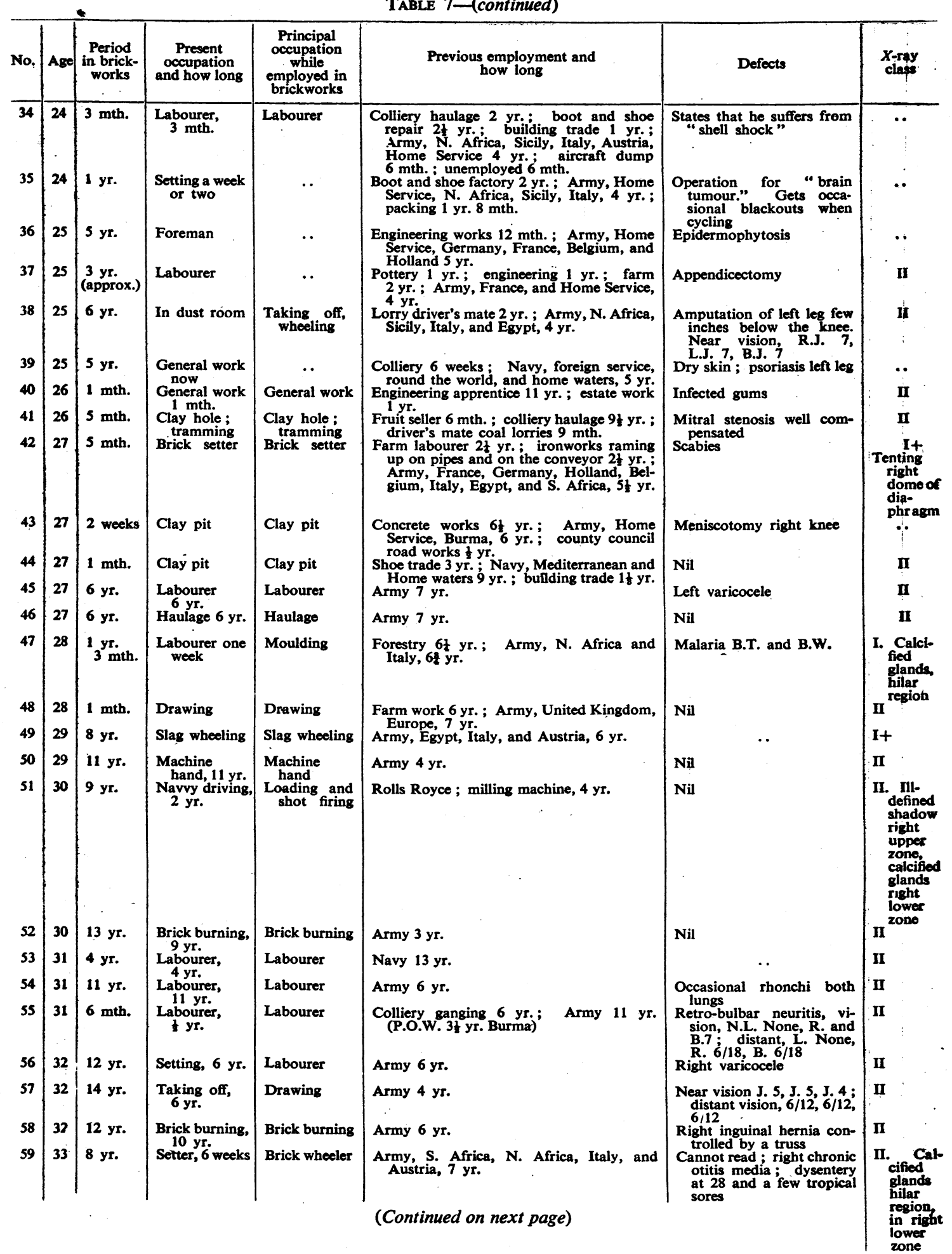


TABLE 7-(continued)

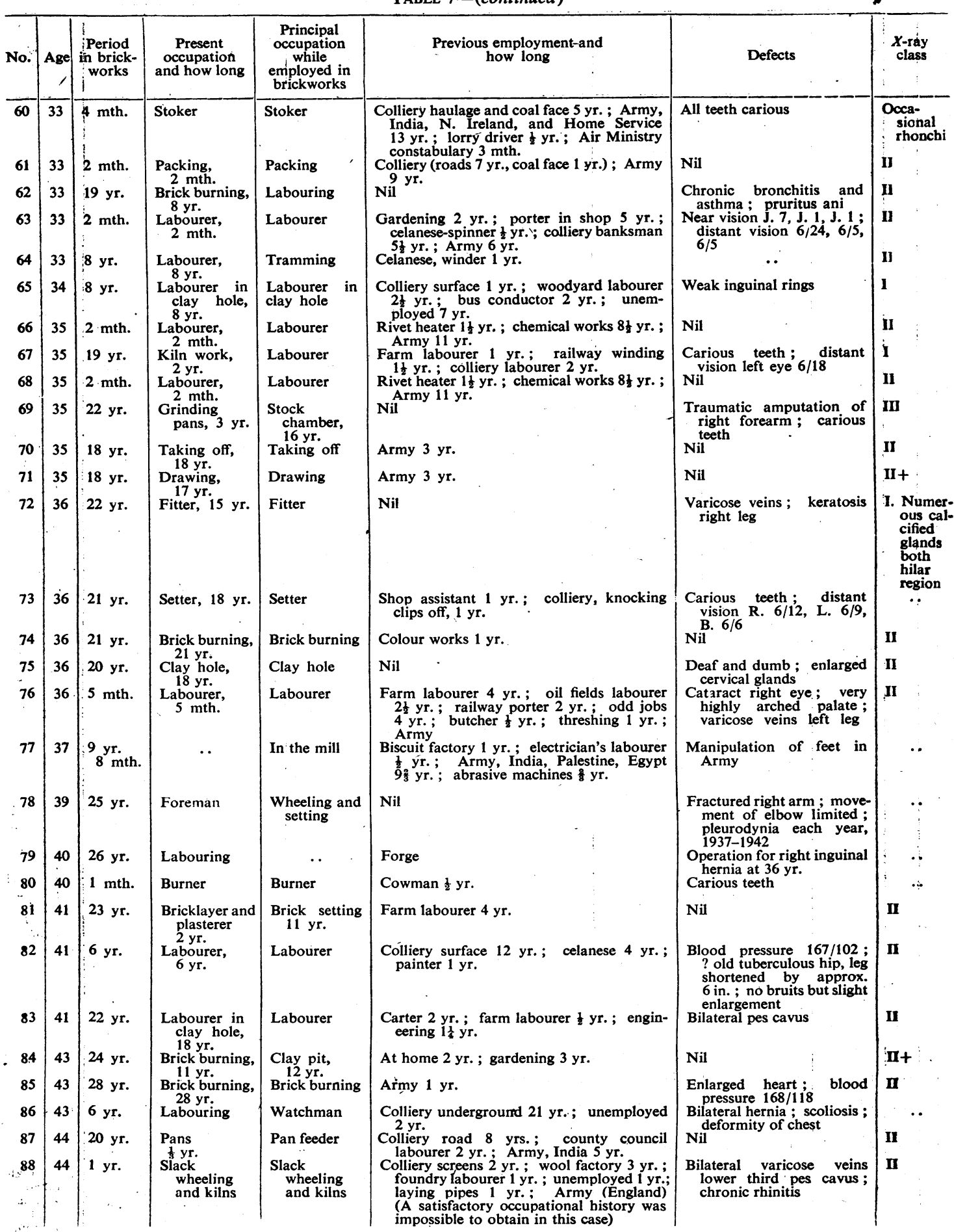

(Continued on next page) 
TABLE 7-(continued)

\begin{tabular}{|c|c|c|c|c|c|c|c|}
\hline No. & Age & $\begin{array}{l}\text { Period } \\
\text { in brick- } \\
\text { works }\end{array}$ & $\begin{array}{l}\text { Present } \\
\text { occupation } \\
\text { and how long }\end{array}$ & $\begin{array}{l}\text { Principal } \\
\text { occupation } \\
\text { while } \\
\text { employed in } \\
\text { brickworks }\end{array}$ & $\begin{array}{l}\text { Previous employment and } \\
\text { how long }\end{array}$ & Defects, & $\begin{array}{l}X \text { ray } \\
\text { class }\end{array}$ \\
\hline 89 & 45 & 3 mth. & $\begin{array}{l}\text { Labouring, } \\
3 \text { mth. }\end{array}$ & & $\begin{array}{l}\text { Gentleman's service } 9 \text { mth.; Army, Home } \\
\text { Service, Middle East, N. Africa, Italy, } \\
\text { lorry driver 7t yr.; machinist and } \\
\text { inspector } 1 \text { yr. }\end{array}$ & Deafness left ear ; dry skin & - \\
\hline 90 & 46 & 24 yr. & Fitter, 24 y.r. & Fitter & Machine shop, fitter $8 \mathrm{yr}$. & $\begin{array}{l}\text { Emphysema both bases ; } \\
\text { keratosis right hand }\end{array}$ & \\
\hline 91 & 46 & 7 yr. & $\begin{array}{l}\text { Quarry } \\
\text { labourer, } \\
7 \text { yr. }\end{array}$ & $\begin{array}{l}\text { Quarry } \\
\text { labourer }\end{array}$ & $\begin{array}{l}\text { Colliery ganging } 7 \text { yr.; colliery coal face } \\
15 \text { yr. ; erector } 3 \text { yr. }\end{array}$ & 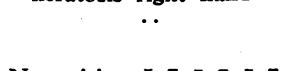 & II+ \\
\hline 92 & 49 & 1 mth. & Labourer & Labourer & $\begin{array}{l}\text { Colliery trapping driving } 3 \text { yr.; Navy } 4 \text { yr. ; } \\
\text { bricklayer's labourer } 5 \text { yr.; engineering } \\
\text { works, labourer } 2 \text { yr. }\end{array}$ & $\begin{array}{l}\text { Near vision, J. 7, J. 7, J. } 7 \text {; } \\
\text { oral hygiene noted }\end{array}$ & $\begin{array}{l}\text { V. Old } \\
\text { rhonchi } \\
\text { noted }\end{array}$ \\
\hline 93 & 51 & 23 yr. & $\begin{array}{l}\text { Labourer, } \\
23 \text { yr. }\end{array}$ & Labourer & Woodyard labourer 2 yr. ; colliery loading & $\begin{array}{l}\text { Near vision (with glasses) } \\
\text { J. 3, J. 8, J. 3; distant } \\
\text { vision (without glasses) } \\
6 / 36,6 / 36,6 / 36\end{array}$ & \\
\hline 94 & .51 & 8 yr. & Drawing & Drawing & $\begin{array}{l}\text { Colliery screens } 3 \text { yr. ; underground and } \\
\text { surface and firing ; odd jobs } 1 \text { yr. }\end{array}$ & $\begin{array}{l}\text { Bilateral varicose veins ; } \\
\text { infected gums; } \\
\text { sional rhonchi }\end{array}$ & $\mathbf{I}+$ \\
\hline 95 & 54 & 2 yr. 6 mth. & Setting- & $\cdots$ & $\begin{array}{l}\text { Ginger beer factory } 18 \text { mth.; railway } \\
\text { signal man } 14 \text { yr. ; motor mechanic } \\
2 \text { yr.; agriculture } 1 \text { yr. }\end{array}$ & $\begin{array}{lll}\text { Nil } & \\
& \ddots & \end{array}$ & $\cdots$ \\
\hline 96 & 61 & 7 mth. & Kiln cleaner & $\cdots$ & $\begin{array}{l}\text { Printing trade } 6 \text { yr.; public house } 1 \text { yr.; } \\
\text { colliery surface } 20 \text { yr.; building trade } \\
10 \text { yr.; odd jobs }\end{array}$ & $\begin{array}{l}\text { Left inguinal hernia ; skin } \\
\text { dry ; low I.Q. ; near } \\
\text { vision (without glasses) } \\
\text { J. 8, J. 8, J. 8; distant } \\
\text { vision } 6 / 18,6 / 18,6 / 18\end{array}$ & . \\
\hline 97 & 63 & $29 \mathrm{yr}$. & Mixing & $\cdots$ & $\begin{array}{l}\text { Shoe making } 7 \text { yr.; concrete sheds } 9 \text { yr.; } \\
\text { Army, France, Home Service, } 5 \text { yr. }\end{array}$ & $\begin{array}{l}\text { Bilateral inguinal hernia ; } \\
\text { exercise tolerance some- } \\
\text { what reduced }\end{array}$ & $\cdots$ \\
\hline 98 & 64 & 6 yr. & $\begin{array}{l}\text { Labourer, } \\
6 \text { yr. }\end{array}$ & Labourer & $\begin{array}{l}\text { Woodyard labourer } 3 \text { yr. ; colliery banks- } \\
\text { man } 9 \text { yr.; colliery labourer } 6 \text { yr. ; } \\
\text { general labourer } 13 \text { yr. }\end{array}$ & $\begin{array}{l}\text { Vision left eye near, J. } 8 \text {; } \\
\text { left eye distant } 6 / 60\end{array}$ & II \\
\hline 99 & 66 & 53 yr. & Burning & .. & Army, N. Africa, Italy, Greece & $\begin{array}{l}\text { Vision (without glasses) } \\
\text { near J. 8, J. 8, J. 8; dis- } \\
\text { tant 6/36, 6/36, 6/36 } \\
\text { (wears glasses) }\end{array}$ & \\
\hline 100 & 66 & 53 yr. & Burning & Burning & $\cdots$ & $\begin{array}{l}\text { Vision (wears glasses for } \\
\text { reading) near J. 8, J. } 8 \text {, } \\
\text { J. } 8 \text {; distant } 6 / 36,6 / 36 \text {, } \\
6 / 36\end{array}$ & $\cdots$ \\
\hline
\end{tabular}

(3) the effect of undue changes of atmosphere and of noxious fumes among those working in the kilns and engaged in the cleaning of flues; (4) the possibility of ill health due to the arduous nature of the work.

Only fitters and workers engaged in taking green bricks off the press come into contact with mineral oil, while continuous work in a very dusty atmosphere is restricted to those operatives who maintain the flow of ground dust from the screens to the mixers. It is true that cleaning out the kilns and unloading them may also be dusty, especially in windy weather when the work may give rise to physical discomfort, but the workers do not stay in the kilns for many minutes at a time.

In the same way the exposure to sulphur dioxide given off in the kilns is intermittent. The only workers who are continuously exposed to sulphur dioxide are the men setting the green bricks. Our tests. were carried out under favourable conditions and in no case did the concentrations reach one part in a million, a figure not substantially higher than is common in the atmosphere of industrial towns. We do not think that the concentration of sulphur dioxide is likely to exceed a few parts per million even in adverse circumstances.

The most striking features of these brickworks are (a) the absence of all forms of mechanized help in the operation of the kilns, and (b) the extreme changes of atmosphere which is the habit of workers in and out of the kilns.

From the time that the stiff plastic brick leaves the press it is handled four times before it leaves the brickworks. The green bricks are transported to the kilns by trolley and then stacked by hand at the rate of about 1,000 per hour. During unloading of the fired bricks these are stacked in fifties on a wheelbarrow and wheeled across the loading bay to waiting lorries. A man employed on this work averages 15,000 bricks per day : he thus makes 300 journeys per day, and each brick is handled twice. Wirecut plastic bricks are handled no less than six times, as they require to be dried before burning can take place.

Men are continually employed both in the hot chambers and out in the open air at regular intervals, and in winter weather extremes of temperature are considerable. The principal risks to health, are the 
monotonous and arduous nature of the work, as well as exposure to extremes of temperature.

An assessment of the physical condition of those entering the industry should therefore be carried out, and to do this a comprehensive medical examination is required. Candidates for employment giving a history of recurrent bronchitis and all those who admit to previous respiratory disease, whatever its nature, should be submitted to $x$-ray examination of the chest before a decision is reached as to their fitness for this type of work. Evidence of tuberculosis of the lungs, active or quiescent, must be regarded as a contraindication to employment.

People with a previous history of skin disease or actually suffering from dermatoses should be excluded if they are likely to come into contact with mineral oil, and attention should also be paid to the type of skin of such persons (Peters, 1944).

The placement examination is paramount in importance, but periodic examination of those exposed to the risk of skin affections should be undertaken every three months, and there should be annual $x$-ray examination of the chest in workers engaged in dusty operations of a continuous nature. As contact with mineral oil seems unavoidable in those taking green bricks off the presses, adequate washing facilities and the provision of a suitable barrier cream are essential to prevent the occurrence of dermatitis and keratotic changes in the skin.

The information about the environment and health of the brickmaker gained as a result of this survey serves to support, and in certain respects to amplify, that published in the Reports of the Committee on Amenities in the Brick Industry (1947). It also indicates the urgent necessity for implementing without delay the recommendations contained in that report.

\section{Summary}

A brief description is given of modern brickmaking methods.

Environmental studies were carried out in a brickworks employing sixty-five workers.

These studies included a survey of atmospheric conditions, the dust hazards, the risk from exposure to fumes, and an investigation into the nature of the mineral oil in use.

In this survey it is shown that the dust hazard is not excessive ; chemical analysis indicates that the material consists mainly of combined silica and alumina.

Traces of sulphur dioxide and hydrogen sulphide were found.
The carcinogenic properties of the mineral oil in use appeared to be low.

The general health of the workers was good. Seventy-three men had chest $x$-ray examinations; "dust changes" in the lungs were noted in two cases.

Two cases of keratotic changes in the skin were seen in workers who had been exposed to contact with mineral oil.

The number of accidents causing injury was very low.

Brick-making does not involve excessive occupational hazards, but it requires considerable physical effort and exposure to extremes of temperature is frequent.

Placement examination is essential to exclude those physically unfit for this work.

Periodic medical examination of certain workers is needed.

The recommendations in the Report of the Committee on Amenities in the Brick Industry should be implemented without delay.

Our thanks are due to the Directors of the Butterley Company Limited for permission to publish this article, to Mr. F. Catchpole, General Manager of the brickworks, for much help in the description of the technical processes; to Mr. E. R. Arnold of the Derby Evening Telegraph for the photographs illustrating brickmaking methods. We must thank Miss D. M. Pullon, Technical Assistant in the Medical Department, and other members of the Medical and Scientific Departments for assistance in the preparation of this paper. Mr. S. R. Cooper gave valuable assistance in the determination of toxic gases and examination of dust samples.

\section{REFERENCES}

Department of Scientific and Industrial Research (1943). "Methods for the Detection of Toxic Gases in Industry : Sulphur for the Detection of Toxic Gas

Department of.Scientific and Industrial Research (1943). "Methods for the Detection of Toxic Gases in Industry : Carbon Monoxide." H.M.S.O. London.

Department of Scientific and Industrial Research (1943). "Method for the Detection of Toxic Gases in Industry : Hydrogen Sulphide." H.M.S.O. London.

Gardner, L. U., Dworski, M, and Delahant, A. B. (1944). J. Industr. Hyg., 26, 7 Henry, S. A. (1946). "Cancer of the Scrotum in Relation to

Keatinge, G. F., and Potter, N. M. (1945). Brit. J. industr. Med.,

Peters, A. D. K. (1944). In “Industrial Medicine." Edited by Rolleston, Sir H., and Moncrieff, A. A. Eyre and Spottis woode. London.

Potter, N. M. (Aug. 2 and 9, 1946). "Micro and Semi-Micro Methods for the Investigation of Airborne Mine Dust." Colliery Guardian.

Registrar General's Decennial Supplement, England and Wales, 1931; Part 11a, Occupational Mortality (1938). H.M.S.O. 1931 ; Part

Report of the Committee on Amenities in the Brick Industry (1947). H.M.S.O. London.

Twort, C. C., and Lyth, R. (1933). J. Hyg., Camb., 33, 464. 